\title{
RECONSIDERING NAFAQAH OF FAMILY RESILIENCE DURING THE COVID-19 PANDEMIC IN ISLAMIC LEGAL PERSPECTIVE
}

\author{
Ridwan Nurdin \\ Fakultas Syariah dan Hukum Universitas Islam Negeri Ar-Raniry \\ Jl. Syeikh Abdur Rauf Kopelma Darussalam, Banda Aceh, Aceh. \\ e-mail: ridwannurdin@yahoo.com \\ Muhammad Ridwansyah \& Zakyyah Iskandar \\ Fakultas Hukum Universitas Sains Cut Nyak Dhien \\ Jl. Ahmad Yani No. 8-9. Gp. Jawa Kota Langsa \\ e-mail: muhammadridwansyah188@yahoo.com, zakyyahiskandar37@gmail.com
}

\begin{abstract}
The main goal of this research is to comprehend deeply the relation between husband and wife relating to the responsibilty of nafaqat in their family. The methodology used is juridical-sociological; where the data analyzed from textual livelihood obligations conditional or current contextual forces that all family members also have a responsible role in terms of living. The results of the study are as follows: that al-Baqarah requires a husband to provide a living to his wife, but in another context, a wife or other family members can play a role in maintaining family resilience during the Covid-19 pandemic resistance. In reality, however, the nafaqat become mutual responsibility of the husband and wife without any objection.
\end{abstract}

\begin{abstract}
Abstrak: Penelitian ini bertujuan untuk mendalami relasi dan tanggung suami dan isteri terkait nafkah sehingga akan diketahui legal bases yang berkembang. Metodologi yang digunakan dalam penelitian ini adalah yuridis-sosiologis, dimana data yang ditelaah dari tekstual kewajiban nafkah dengan kondisional atau kontekstual sekarang yang memaksa bahwa semua anggota keluarga juga punya peran tanggungjawab dalam hal nafkah. Hasil penelitian menunjukkan bahwa dalam Q.S. al-Baqarah mewajibkan seorang suami memberikan nafkah kepada istri tetapi dalam konteks lain, seorang istri atau anggota keluarga lain dapat berperan dalam menjaga ketahanan keluarga di masa pandemi covid-19. Realitasnya, nafkah keluarga menjadi tanggung bersama suami isteri tanpa ada merasa keberatan.
\end{abstract}

Keywords: nafaqat, family resilience, Covid-19 pandemic 
MIQOT Vol. 45 No. 1 January-June 2021

\section{Introduction}

According to research done by the Department of Family and Consumer Sciences, Faculty of Human Ecology, Bogor Agricultural Institute, explained that one of the factors that determine family harmony is family resilience, including young married families, or all ages of marriage. Family resilience is the ability of the family to manage its resources and overcome the problems it faces, to meet the physical and psychosocial needs of the family. Family resilience will be achieved if the family is spared from economic problems and non-economic problems. The decreasing economic problems experienced by the family can automatically reduce the resilience of the family. ${ }^{1}$

Family resilience here is interpreted as follows, physical family resilience, social family resilience, and psychological family resilience. In the literature, it is explained that the physical family resilience is defined as the economic capacity possessed by the family, namely the components of family members in obtaining economic resources from outside the system to meet basic needs such as food, clothing, shelter, education, and health. Then social resilience is defined as family resilience in applying religious values, maintaining good crisis management mechanisms as well. Then finally, family psychological resilience is the ability of family members to manage emotions, resulting in a positive self-concept. ${ }^{2}$

On the other hand,family resilience is very equivalent to household livelihoods; the concept of living itself is taken from al-nafaqat which means spending. If it is classified as spending, then the living is something that is given by a husband to his wife, a father to a child, and relatives of his property as basic necessities for them. Then the word "living" also has the meaning that all living expenses are the right of the wife and children in terms of food, clothing and shelter as well as several other basic necessities, even if the wife is a rich woman. ${ }^{3}$

That the obligation of a person to spend a living to those who have the right to receive it, such as the husband has the right to provide for his wife, children, even the main income is given aims to meet the basic needs of life, namely food, clothing and a place to live, the obligation to provide for this given according to his ability, it can be adjusted according to their needs and abilities so that they are in harmony with their circumstances and living standards. Then, the problem is how the reformulation of the text of the Qur'an gives the husband the obligation to provide food and clothing to mothers in a good manner. ${ }^{4}$

${ }^{1}$ Tin Herawati, et all., "Dukungan Sosial dan Ketahanan Keluarga Peserta dan Bukan Peserta Program Nasional Pemberdayaan Masyarakat (PNPM) Mandiri," Jurnal Ilmu Keluarga dan Konsumen 5, no. 1 (2020).

${ }^{2}$ Euis Sunarti, "Studi Ketahanan Keluarga dan Ukurannya: Telaah Kasus Pengaruhnya terhadap Kualitas Kehamilan," (Thesis Doctoral, Graduate Program Bogor Agritucal University, 2001).

${ }^{3}$ Syamsul Bahri, "Konsep Nafkah dalam Hukum Islam," Kanun Jurnal Ilmu Hukum, no. 66 Th. XVII, 381.

${ }^{4}$ Zakaria Ahmad Al-Barry, Ahkamul Auladi Fil Islam (Jakarta: Bulan Bintang, 1977), 74. 
Other data from BPS (Central Bureau of Statistics) in 2018 shows that the physical endurance of the family shows that less than $37 \%$ of households who at least 14 times a week can eat completely, staple foods with vegetable or meat dishes. However, many households lost their income during the pandemic, the family resilience dimension of physical resilience could decrease significantly without government assistance. This means that the loss of income for many households in Indonesia has a major impact on the ability to meet family food. The government's decision to provide social assistance can prevent a decline in family resilience. ${ }^{5}$

Another variable in the background of this article regarding the covid-19 pandemic according to the World Health Organization (WHO) is a global pandemic which is defined as an event of the spread of the 2019 coronavirus disease. Classically named SARS CoV2, the Covid-19 pandemic outbreak was first detected in Wuhan City, Hubei Province, Republic of China on December 1, 2019 and designated by WHO as a global pandemic on March 11, 2020. In fact, according to data, up to September 17, 2020 more than $29.864,555$ cases had been reported from 210 countries and regions worldwide, resulting in more than 940,651 people died and more than 20,317,519 people recovered. Medically, the SARS$\mathrm{CoV}-2$ virus is thought to spread between people mainly through respiratory droplets produced during coughing. These splashes can also result from sneezing and normal breathing. In addition, the virus can be spread by touching someone's face. ${ }^{6}$

Covid-19 is most contagious when people who are suffering from it having symptoms, although spread may occur before the symptoms appear. The time period between exposure to the virus and the appearance of symptoms is usually around five days, but can range from two to fourteen days. Symptoms include fever, cough and shortness of breath. Compilation can be pneumonia and severe acute respiratory disease. There is no vaccine or specific antiviral treatment for this disease. The primary treatment given is symptomatic and supportive therapy. Then another alternative in terms of prevention is washing hands, covering mouth when coughing, keeping a distance from other people, and monitoring and self-isolation for people who suspect that they are infected. ${ }^{7}$

From the description above, it is explained that the reformulation of livelihoods for family resilience during the Covid-19 pandemic has become a unity that creates family problems that exist in Indonesia and in Aceh. Moreover, for Muslim it is important to be able to interpret surah al-Baqarah verse 233 which originally positioned the father or husband as the breadwinner. However, contextually the shift in the meaning of the verse has to be

${ }^{5}$ Sonny Harry B. Harmadi, "Ketahanan Keluarga di Masa Pandemi," accessed November 4, 2020, https://mediaindonesia.com/read/detail/323946-ketahanan-keluarga-di-masa-pandemi.

${ }^{6}$ Nicole Lurie, et al., "Developing Covid-19 Vaccines at Pandemic Speed," The New England Journal of Medicine 2, no. 3 (2020), 1971.

${ }^{7}$ Bill Gates, "Responding to Covid-19-A Once in a Century Pandemic?," The New England Journal of Medicine 2, no. 3 (2020), 1677. 
accepted that family security must be guaranteed by all family members. Then, Article 83 of the KHI becomes an opportunity to shed some light in the situation of the Covid-19 pandemic where textual "the main obligation for a wife is to devote physically and mentally to her husband within the boundaries justified by Islamic law". The initial hypothesis that the word was emerged in filial piety to the husband could be interpreted sociologically that a wife can help her husband or other family members who are deemed worthy and capable and do not violate the provisions of Islamic law. ${ }^{8}$

\section{Literature Review}

There are several literature studies in this article, including: reformulation, income, family resilience, and the Covid-19 pandemic, these four variables make up the fundamental project. According to the Indonesian dictionary, the word reformulation comes from the basic word formula which is defined as a formula, if you add the initial re-formula; it is interpreted as a reformulation because the word "re" means re-meaning. In terms of reformulation is reformatting whatever situation that exists because it is far from ideal. As usual, the word reformulation is often used in policies that have initially been implemented. The word reformulation cannot be separated from the word formulate which implies formulation. ${ }^{9}$

Review of norms is commonplace and natural as long as it is considered irrelevant at this time. Reformatted in theory is a very natural thing from the theory of statutory science which was initiated by Hans Kelsen by using the norm-level theory, and continued by Hans Nawiasky, emphasizing that in addition to tiered norms, norms are also grouped and grouping of legal norms within a country. Then, the problem is how to reformulate the holy verses which are considered by some ordinary Muslims cannot be replaced both textually and contextually. Meanwhile, some interpretations provide the possibility to open up new interpretations for the Qur'an because the Qur'an is always open to new interpretations and is never certain and closed in a single interpretation. This means that in the context of the holy verses, human understanding of the Qur'an will be greatly influenced by its historicity as a human being. When and where he lived will be part of his interpretation of the Qur'an. ${ }^{10}$

The other side of reviewcan also be related to the concepts of nâsikh and mansûkh

${ }^{8}$ Arya Hadi Dharmawan, "Sistem Penghidupan dan Nafkah Pedesaan: Pandangan Sosiologi Nafkah Mazhab Barat dan Mazhab Bogor," Sodality: Jurnal Transdisiplin Sosiologi, Komunikasi, dan Ekologi Manusia (2007), 169.

${ }^{9}$ See Antik Bintari and Londrikus Hartarto, "Formulasi Kebijakan Pemerintahan tentang Pembentukan BUMD," Jurnal Imu Pemerintahan 2, no. 2 (October 2015).

${ }^{10}$ See Muhammad Busyrol Fuad, "Reformulasi Norma Hak dan Kewajiban Suami Istri dalam Hukum Keluarga di Indonesia: Sebuah Upaya Pengarusutamaan Gender dalam Pembaharuan Undang- Undang Nomor 1 Tahun 1974 tentang Perkawinan," (Undergraduate Thesis, Maulana Malik Ibrahim State Islamic University, 2016). 
in Islamic law. Whereas the concept of nasikh is to repeal the shari'a law with the argument of shari'a. Nasakh is also interpreted as nullifying the law obtained from the first text on the basis of the texts that came later. This means abolishing the shari'a law by using the argument of syara' with the grace period between the first law and the next law, provided that if there was no nash, the first law would still apply. ${ }^{11}$

However, the concepts of nâsikh and mansûkh are limited to equal arguments, meaning that the verses of the Qur'an are the same as the verses of the Qur'an. For example, the Qur'an surah al-Baqarah verse 240 is deleted by verse 234, and there are many other examples. What becomes a dilemma and debate is whether the meaning of the verse content changes during an emergency. Then the question is whether reformulation is the same as the concept of nasikh and mansûkh in Islam. The Qur'an itself informs that there are 56 verses in the Qur'an regarding livelihood which include 73 words of living. That is, living in the Qur'an is the expenditure of every property that is owned from lawful assets which is proclaimed as a way of goodness to get closer to God and is aimed at every need of life that is justified by the Qur'an. However, theologically, the existence of a living is derived from God, this phrase also insinuates that basically sustenance is from God, so the distribution of livelihoods in harmony in the Qur'an is intended for parents, wives, children, relatives, orphans, the poor, Ibnu sabil, and wives who are divorced while pregnant and who are considered relevant in the context of the argument. ${ }^{12}$

The next literatureis family resilience; it consists of two words, resilience and families. The word resilience is defined as being in its state, its position, despite experiencing various things, does not break quickly and so forth. The word family in the Indonesian dictionary means mother, father and children in the whole house. In terms of family resilience is the dynamic condition of the family in managing physical and non-physical resources and managing the problems faced, to achieve the goals of a quality and resilient family as the main foundation in realizing national resilience. At first glance, it has been conveyed in the background regarding family resilience, but the concept of family resilience needs to be further explained. ${ }^{13}$

The most important thing in family resilience is the commitment of all family members, husband, wife and children. If the commitment is not agreed earlier, any challenges will be heavy and it is certain that a family can collapse. Family resilience (family strength) is a condition of adequacy and continuity of access to income and resources to meet various basic needs, technically such as food, clean water, health services, educational opportunities, housing, time to participate in society and social integration. Family resilience is also defined

${ }^{11}$ See Fuad, "Reformulasi."

${ }^{12}$ Imam Masrur, "Konsep Nasikh Mansukh Jalauddin Al-Suyuti dan Implikasi Metode Pengajarannya di Perguruan Tinggi," Realitas Journal 16, no. 1 (2018).

${ }^{13}$ Muhammad Hasby Al-Shiddieqy, Sejarah dan Pengantar Ilmu Alquran dan Tafsir (Semarang: Pustaka Rizki Putra, 2000). 
by the Government of Indonesia through the Ministry of Women's Empowerment and Child Protection that family resilience is the ability of a family to develop it to live in harmony, prosperity and happiness both physically and mentally. Other literature explains that family resilience is family ability to manage resources and problems to achieve prosperity, ability to survive and adapt to various conditions that are constantly changing dynamically and have a positive attitude towards various challenges in family life. ${ }^{14}$

The classification of family resilience, the family's ability to ward off or protect themselves from various problems or life threats, both from within their own family and from outside the family, such as the environment, community, society, country, and the Covid-19 pandemic. Admittedly or not, the Covid-19 pandemic has become a new challenge for family resilience in today's global context. Family resilience amid the Covid-19 pandemic has been disrupted due to the large number of workers being laid off, and the decreasing income of the head of the family (husband)..$^{15}$

The latest literature regarding the covid-19 pandemic, its term has been explained in advance regarding the covid-19 pandemic in the background. But the question is what exactly is the covid-19 pandemic that can disrupt economic stability and world health stability, even the smallest unit in this country is the family at the same time affected by the covid-19 pandemic. $^{16}$

As a result of the Covid-19 pandemic, some countries have even increased state debt including Indonesia because of the massive spread of the virus and no vaccine has been found to overcome the virus. Technically, the spread of the virus is transmitted through droplets (splashes of saliva) that are produced when an infected person coughs, sneezes, or exhales. This droplet is too heavy and cannot stay in the air so it can quickly fall and stick to the floor or other surface. On the other hand, from the data that has been described, the outbreak of the Covid-19 pandemic that is most affected by this outbreak is micro and macro businesses. When micro and macro businesses are the sectors most affected, there are restrictions on community activities so that they automatically affect the economy. ${ }^{17}$

In the context of Islam, it is true that the husband has given full responsibility for living, but when there is an emergency element, and then the issue of health and economic emergencies needs to review the burden of livelihoods which is only on the husband's right.

\footnotetext{
${ }^{14}$ Euis Sunarti, et al., "Perumusan Ukuran Ketahanan Keluarga," Media Gizi dan Keluarga 27, no. 1 (Juli 2003), 11.

${ }^{15}$ Imas Novita Juaningsih, "Analisis Kebijakan PHK Bagi Para Pekerja Pada Masa Pandemi Covid-19 di Indonesia," Majalah Adalah: Buletin Hukum dan Keluarga 4, no. 1 (2020).

${ }^{16}$ Dito Aditia, et al, "Dampak Pandemi Covid-19 terhadap Perekonomian di Indonesia," Jurnal Beneftia 5, no. 2 (Juli 2020), 212.

${ }^{17}$ Ibid.
} 
This means that in this literarature of review, it becomes the substance of the discussion chapter. ${ }^{18}$

\section{Methodology}

The method used in this research is juridical-sociological, in which the main focus of this article is secondary data, which consists of primary legal materials, secondary legal materials, and tertiary legal materials. Primary legal materials will study and review the text in al-Baqarah article 233 with the phrase "the father's obligation to bear their livelihood and clothing in an appropriate manner". The phrase of this verse will be approached with three approaches, including: historical approach, how asbâb al-nuzûl came down this verse, the existence of society at that time so that the common thread of verse historicity emerged and conclusions could be drawn. The conceptual approach, this approach is present to examine and review the conceptual of the father in terms of bearing a living, or even see the values contained in al-Baqarah verse 233. Finally, the sociological approach is carried out more on community objects such as communities affected by the Covid-pandemic. 19. It means that the phenomenon of society in order to understand and study al-Baqarah verse 233 requires a careful sociological approach so that the interpretation of verses in the past can be compared when the context has changed with the presence of the Covid-19 pandemic. ${ }^{19}$

\section{Results and Discussion}

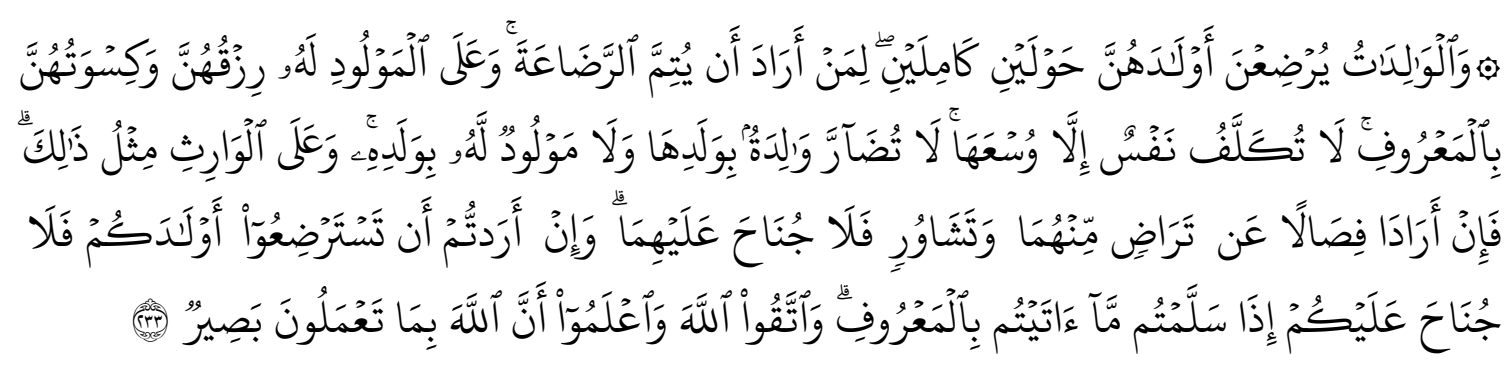

Mothers may breastfeed their children two complete years for whoever wishes to complete the nursing [period]. Upon the father is the mothers' provision and their clothing according to what is acceptable. No person is charged with more than his capacity. No mother should be harmed through her child, and no father through his child. And upon the [father's] heir is [a duty] like that [of the father]. And if they both desire weaning through mutual consent from both of them and consultation, there is no blame upon either of them. And if you wish to have your children nursed by a substitute, there is no blame upon you as long as you give payment

${ }^{18}$ Kemenkes RI., Pedoman Pencegahan dan Pengendalian Coronavirus Disease 2019 (Jakarta: Direktur Jenderal Pencegahan dan Pengendalian Penyakit, 2020), 23.

${ }^{19}$ Mark Van Hoecke, Epistemology and Methodology Comparative Law (North America: Oxford and Proland, 2004), 299. 
MIQOT Vol. 45 No. 1 January-June 2021

according to what is acceptable. And fear Allah and know that Allah is Seeing of what you do. (Q.S. al-Baqarah/2: 233).

Textually the above verse is inseparable parts because it has the same spirit in a series of one verse. However, in the textual phrase, there are three main things that are informed: Firstly, mothers should breastfeed their children for two full years. Secondly, it is the father's obligation to feed and clothe the mothers in a good manner. Thirdly, do not let a mother suffers misery because of her child and a father experiences the same thing because of his child. In essence, this article focuses on the second point is how the actual obligation of fathers to bear their livelihoods and clothing in a proper way during the Covid-19 pandemic. Although there are other translations that say to feed and bear a living, it is still the reference to bear a living because it is considered more relevant from the language aspect. $^{20}$

Based on its interpretation, the phrase the father's obligation to support this living is recommended in the custom that applies to them in their respective places, not exaggerating or too less in accordance with the father's ability in terms of income. The main problem when there is the word to bear a living, it can not be further interpreted that it is not only the figure of the father but all members of the family who are able. According to the next text, "Do not let a mother suffer misery because of her child and a father because of his child, and the heritor is obliged to do so." The relationship between mother, child, and father cannot be separated in kinship relationships. Therefore, the burden or responsibility is often narrowly interpreted it and only limited to the father. ${ }^{21}$

The phenomenon of the covid-19 pandemic sociologically forces Islamic jurists to re-examine whether the burden is appropriate for husbands during the Covid-19 pandemic or is it only conditional. However, in the hadith, it was reported that Abu Bakr's son, Asma bint Abu Bakr, was a businesswoman who worked hard and was pious to help or support the family economy, but at that time there was no plague found, it happened that her husband was not as lucky as Asma binti Abu Bakr. ${ }^{22}$

The view of Islamic law, Syekh al-Qardhawi emphasizes that when the wife works outside the record is as follows: the work done must be lawful, not inviting seclusion, not

${ }^{20}$ Siti Rukhaini Dzhayatin, et al., Kesetaraan antara Perempuan dan Laki-Laki dalam Reformulasi Metodologis (Yogyakarta: Pustaka Pelajar, 2016). See also Mhd. Syahnan, et al., "Reconsidering Gender Roles in Modern Islam: A Comparison of the Images of Muslim Women Found in the Works of Sayyid Qutb and 'Â'ishah 'Abd Rahmân," International Journal of Humanities and Social Science Invention 6, no. 10 (2017), 37-42.

${ }^{21}$ Muhammad Quraish Shihab, Tafsir Al-Misbah: Pesan, Kesan dan Keserasian Alquran (Jakarta: Lentera Hati, 2005).

${ }^{22}$ Nurvitasari, "Asma Binti Abubakar: Peranannya dalam Hijrah Nabi Muhammad SAW ke Madinah dan Periwayatan Hadis," (Undergraduate thesis, Surabaya: State Islamic University of Sunan Ampel, 2004). 
hurting the family and husband, and not neglecting their children. Because the work of the wife will get results at the same time become the absolute property of the wife, but one hadith explains that when a Muslim provides a living to his family he expects merit from him, it is worth almsgiving. ${ }^{23}$

The fuqaha explained that the father's responsibility as a provider was absolutely not excessive or not too little, according to the ability of the father, rich, medium or poor. Here, fuqaha usually emphasizes the factors that cause a man as the head of the household to work and earn income. On the other hand, not only to meet personal needs, but also to provide for their wives and children. Of course, the above interpretations will not be blamed as long as conditions do not change as they are now. In the hadith it has also been explained that in the context of helping wives, it is justified in supporting the family economy. ${ }^{24}$

Then, historically the existence of al-Baqarah article 233 is closely related to the command that mothers should breastfeed their children for two full years, then in the Arabic tradition a mother who is breastfeeding her children is usually a husband as a reward for his wife who is breastfeeding. In this case we see that Islam highly respects the dignity of women and protects women. There is even a special gift when a wife breastfeeds her children. The text of the verse a quo explains that after the divorce, when the woman is pregnant, the husband is obliged to provide for the wife and even exaggerates some of it. This means that the husband's obligation to support the children without limits, this must be interpreted as a consequence of the family relationship between the child and the father. ${ }^{25}$

According to other interpretations, the text of the al-Baqarah article 233 is dominant towards the obligation to breastfeed the mother, not to others. Only give the child to another person if the mother is unable to do so. Medically, breast milk is the best food for babies and even breast milk will be able to increase in number along with the needs of the baby's life at that time. However, besides the breastfeeding process, there are fathers who are obliged to meet the needs of mothers who are breastfeeding, meaning that the role of fathers cannot be neglected in the process of caring for children since childhood. However, during the Covid-19 pandemic, wives can assist their wives as long as their husbands are in an emergency. In fact, it is hoped that the husband can help the role of the wife while at home because according to the hadith of Aisyah ra., the Prophet Muhammad PBUH was also helping Aisyah at that time in household chores. ${ }^{26}$

It can be interpreted and understood that the existence of al-Baqarah article 233 is

${ }^{23}$ Yusuf Al-Qhardawi, Fatwa-Fatwa Kontemporer (Jakarta: Gema Insani Press, 1997).

${ }^{24}$ Ibid.

${ }^{25}$ Irma Riyani, "Menelusuri Latar Historis Turunya Alquran dan Proses Pembentukan Tatanan Masyarakat Islam," Al-Bayan: Jurnal Studi Alquran dan Tafsir 1, no.1 (June 2016), 27. Compare with Mhd. Syahnan, "The Image of the Prophet and the Systematization of Ushul al-Fiqh: A Study of al-Shafi'i's Risalah," Jurnal Miqot no. 103 (1998) 44-50.

${ }^{26}$ See Hamka, Tafsir Al-Azhar (Jakarta: Pustaka Panjimas, 1992). 
an important point in building family resilience during the Covid-19 pandemic. Husbands cannot run away from their role of supporting the family, when the husband cannot provide for his wife or children, and the dominant position of income is in the wife, then the role of the husband must be changed to the domestic role of the family. This means that family resilience must be accompanied by the duties of each husband and wife. So the resilience of families during the Covid-19 pandemic is not only materially able to survive but can survive in non-material conditions which are no less important. ${ }^{27}$

The interpretation of bearing a living cannot be narrow and singular, meaning that the potential of the family must all be developed. When all members play an active role, family resilience is more maintained, but when one family member does not play a role in his duties, it is certain that the family's resilience will collapse even though it is not during the Covid-19 pandemic. $^{28}$

Juridically, Article 83 paragraph (1) of Presidential Instruction No. 1 of 1991 concerning Dissemination of Compilation of Islamic Law "The main obligation for a wife is to have physical and spiritual filial piety to her husband within which is justified by Islamic law". The phrase filial piety to the husband can be interpreted as helping the family economy when the husband's income is not sufficient. That is, allowing as long as it does not complicate and harm the wife's condition. Because basically, KHI originates from the formulation of Islamic legal principles which are systematically arranged as completely as possible by referring to the formulation of sentences or articles commonly used in statutory regulations. It has even become a standard reference used in making decisions within the religious courts. So the concept of filial piety has already passed a fairly well-established debate phase. ${ }^{29}$

Furthermore, the conceptual al-Baqarah article 233 and Article $83 \mathrm{KHI}$ both have their own continuity. The father as the breadwinner is helped by the position of the wife who helps the family economy during an emergency. It needs to be emphasized as long as the work does not contain elements that are harmful to the wife and family concerned. So, family resilience during the Covid-19 pandemic really needs to work together with all family members when the wheels of the family economy also drop dramatically. Families in Indonesia must be able to pass this emergency phase, one of the basic principles of ushul fiqh that preventing damage is better than bringing good. It can be expanded that when family life is threatened during the Covid-19 pandemic, a wife who is considered capable

${ }^{27}$ See Muhammad Ridwansyah, "Nafkah Anak Luar Kawin Menurut Konsep Hifzhul AlNafs," Jurnal Yudisial 8, no. 1 (2015).

${ }^{28}$ A. Manan, "Penemuan Hukum oleh Hakim dalam Praktek Hukum Acara di Peradilan Agama," Jurnal Hukum Dan Peradilan 2, no. 2 (2013), 190. See also Mhd. Syahnan and Abd. Mukhsin, "Islamic Law of Procedure: An Analysis of Kitâb al-Qâdhî ila al-Qâdhî in Islamic Legal Literature," Islamijah: Journal of Islamic Social Sciences, 1, no. 1 (2020), 97-106.

${ }^{29}$ See Abdul Manan, Aneka Masalah Hukum Perdata Islam di Indonesia (Jakarta: Prenada Media, 2008). 
of supporting this household is justified on the basis of obtaining goodness in order to survive in the midst of the outbreak. ${ }^{30}$

Then, another law of ushul figh explains that kemudharatan allows things that are prohibited. Although basically wives according to classical fiqh appear to be prohibited from working outside the home, in the context of the Covid-19 pandemic it is permissible as long as it is not dangerous and maintains health protagonists. If the condition of family resilience is very dangerous, the purpose of maqashid al-sharia is threatened because it keeps the soul in the rank of daruriyyat and maintains offspring in meeting family needs. But when the husband actively returns to work after the covid-19 pandemic has subsided, if the wife returns to her original position as the caregiver of the family. ${ }^{31}$

The further analysis in the textual of the Qur'an that a wife only lives at home and serves her husband, this is based on Surah al-Ahzab/33: 33 as follows:

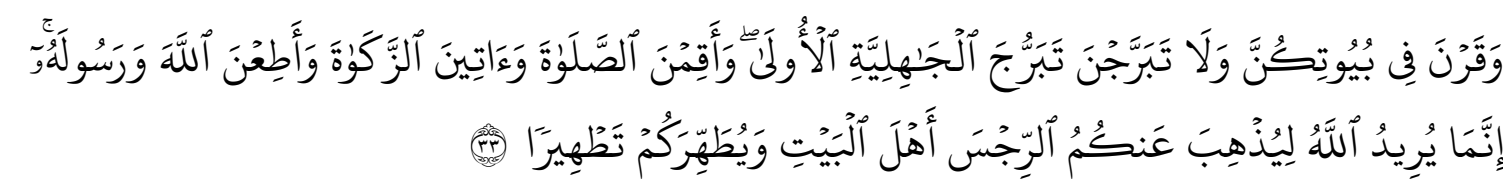

The meaning: And let you stay in your house and do not be decorated and behave like the people of the past Jahiliyah and establish prayers, pay zakat and obey Allah and His Messenger. Indeed, Allah intends to remove sins from you, Ahlul Bait and cleanse you as clean as possible.

If you examine the word qarna, there are those who read iqrarna, qurt'ain qirna and waqar which means authority and respect, meaning that the verse is understood to be at home because it will bring dignity and respect to you. Another interpretation explains that the meaning of the above verse is an order to stay at home. Although the editorial of the verse is addressed to the prophet's wife, apart from them, it is also covered by this command. Literally, it is the position of women who live in their homes and do not go out unless there is an emergency. ${ }^{32}$

Meanwhile, a rather contemporary view that surah al-ahzab verse 33 only indicates that the household is the main wife of the wife, but other than that it is not permanent, it means that it is not her main task. The research team is more focused that there were women in the early Islamic era who worked when economic conditions according to them. During the current Covid-19 pandemic, all family members can work because they have entered the emergency element according to maqashid al-syari'ah. Another problem also lies not only in the presence or absence of their right to work, but Islamic law does not tend to encourage women to leave the house except for jobs that are very necessary. The current

\footnotetext{
${ }^{30}$ Hamid Sarong, Hukum Perkawinan di Indonesia (Banda Aceh: PeNA, 2010).

${ }^{31}$ T. Syahuri, Legislasi Hukum Perkawinan di Indonesia: Pro dan Kontra Pembentukannya hingga Putusan Mahkamah Konstitusi (Jakarta: Kencana Prenada Media, 2013).

${ }^{32}$ Al-Qurtubi, Tafsîr al-Qurthubî (Cairo: Dâr El-Hadith, 1993), 3.
} 
context is that there are many husbands whose income has been dismissed or cut due to the response to the Covid-19 pandemic, so that the wife needs to work outside the home in terms of the need to work because no one supports or survives for her family so that a wife is allowed to work.

The narratives above explain that a wife is allowed to leave the house to work except for an emergency that is haram. The second is allowed but prioritizes household duties, the law is makruh. Then, it is permissible but more importantly stay in the house of the law of circumcision Following are some re-analysis of nafaqah on family resilience during the Covid-19 pandemic. First, when a husband finds it difficult to provide for his wife and family. Sharia provides a choice for a wife whose husband is unable to provide a living between applying for fasakh or remaining as a wife. Second, when the husband in his income or income is limited while the wife has the ability or opportunity in terms of living but with the conditions that they must remain trustworthy and do not take orders prohibited by religion. Third, when giving a living to a husband during the Covid-19 pandemic is a very good thing. This is when it occurs in the position of a career wife. Fourth, if a wife earns a living with the intention of her existence and is bored at home not because of an emergency element, in the opinion of some classical fiqh it is prohibited. Fifth, when the needs of households in the modern era have been helped a lot by technology, the position of earning a living can actually be changed. This means that many women today are highly educated. When in religion there are no restrictions on their work, it is very permissible for women to also work outside the domestic market. ${ }^{33}$

It can be understood as the rule of ushul fiqh as follows: all matters (cases) depend on the purpose, there is no reward and sanctions if something is done without intention".When the Covid-19 pandemic appears and endangers the economic resilience of the family, a wife can innovate to help a husband maintain the family economy. ${ }^{34}$

\section{Conclusion}

From the discussion above, there are at least two very basic conclusions that could be drawn as follows: First, that the Qur'anic verse of al-Baqarah requires a husband to provide a living to his wife, but in another context, a wife or other family member can play a role in maintaining family resilience during the Covid-19 pandemic resilience pandemic. However, it needs to be understood that wives who work in the context of helping ease the husband's duties as the main bearer of the matter of living. When the Covid-19 pandemic ends, the original position must change completely and the wife's income has absolute

${ }^{33}$ Elimartati, "Hukum Istri Mencari Nafkah dalam Tinjauan Maqashid Syari'ah," Islam Transformatif: Journal of Islamic Studies 2, no. 2 (2018).

${ }^{34}$ Djazuli, Kaidah-Kaidah Fikih: Kaidah-Kaidah Hukum Islam dalam Menyelesaikan MasalahMasalah yang Praktis (Jakarta: Kecana 2006), 3. 
rights if you want to use it for family needs, you must first give permission to the wife concerned. On the other hand, a wife who helps the family economy, God will reward her more. Second, then, Article 80 paragraph (4) letter a KHI explains that the husband is responsible for his income for the wife, but Article $83 \mathrm{KHI}$ explains that a wife has only the main obligation to serve physically and mentally, the meaning of filial piety may be interpreted as a form of assistance or partially alleviating the husband's duty in terms of living when a wife is in the capable category and there is no element of coercion.the family become unity and responsibilty in mutual understanding and effortto solve any problem caused by covid 19 which is of course the very tenet of the Islamic teachings.

\section{References}

Aditia, Dito, "Dampak Pandemi Covid-19 terhadap Perekonomian di Indonesia." Jurnal Beneftia 5, no. 2 (Juli 2020).

Ahmad al-Barry, Zakaria. Ahkâm al-Aulâdi fi al-Islâm. Jakarta: Bulan Bintang, 1977.

Al-Qardhâwî, Yûsuf. Fatwa-Fatwa Kontemporer. Jakarta: Gema Insani Press, 1997.

Bahri, Syamsul. "Konsep Nafkah dalam Hukum Islam.” Kanun Jurnal Ilmu Hukum, no. 66 Th. XVII.

Bintari, Antik dan Londrikus Hartarto. "Formulasi Kebijakan Pemerintahan tenang Pembentukan BUMD.” Jurnal Imu Pemerintahan 2, no. 2 (October 2015).

Busyrol Fuad, Muhammad. "Reformulasi Norma Hak dan Kewajiban Suami Istri dalam Hukum Keluarga di Indonesia: Sebuah Upaya Pengarusutamaan Gender dalam Pembaharuan Undang-Undang Nomor 1 Tahun 1974 tentang Perkawinan." (Undergraduate Thesis, Maulana Malik Ibrahim State Islamic University, 2016).

Djazuli. Kaidah-Kaidah Fikih: Kaidah-Kaidah Hukum Islam dalam Menyelesaikan MasalahMasalah yang Praktis. Jakarta: Kecana 2006.

Dzhayatin, Siti Rukhaini. Kesetaraan antara Perempuan dan Laki-Laki dalam Reformulasi Metodologis. Yogyakarta: Pustaka Pelajar, 2016.

Elimartati. "Hukum Istri Mencari Nafkah dalam Tinjauan Maqashid Syariah." Islam Transformatif: Journal of Islamic Studies 2, no. 2 (2018).

Gates, Bill. "Responding to Covid-19- A Once in a Century Pandemic?.” The New England Journal of Medicine 2, no. 3 (2020).

Hadi Dharmawan, Arya. "Sistem Penghidupan dan Nafkah Pedesaan: Pandangan Sosiologi Nafkah Mazhab Barat dan Mazhab Bogor." Sodality: Jurnal Transdisiplin Sosiologi, Komunikasi, dan Ekologi Manusia (Agustus 2007).

Hamka. Tafsir Al-Azhar. Jakarta: Pustaka Panjimas, 1992.

Harry B. Harmadi, Sonny. "Ketahanan Keluarga di Masa Pandemi." Accessed November 4, 2020, https://mediaindonesia.com/read/detail/323946-ketahanan-keluarga-di-masapandemi. 
MIQOT Vol. 45 No. 1 January-June 2021

Hasby Al-Shiddieqy, Muhammad. Sejarah dan Pengantar Ilmu Alquran dan Tafsir. Semarang: Pustaka Rizki Putra, 2000.

Herawati, Tin. "Dukungan Sosial dan Ketahanan Keluarga Peserta dan Bukan Peserta Program Nasional Pemberdayaan Masyarakat (PNPM) Mandiri." Jurnal Ilmu Keluarga dan Konsumen 5, no. 1 (Januari 2020).

Hoecke, Mark Van. Epistemology and Methodology Comparative Law. North America: Oxford and Proland, 2004.

Juaningsih, Imas Novita. "Analisis Kebijakan PHK Bagi Para Pekerja Pada Masa Pandemi Covid-19 di Indonesia." Majalah Adalah: Buletin Hukum dan Keluarga 4, no. 1 (2020).

Kemenkes RI. Pedoman Pencegahan dan Pengendalian Coronavirus Disease 2019. Jakarta: Direktur Jenderal Pencegahan dan Pengendalian Penyakit, 2020.

Lurie, Nicole. "Developing Covid-19 Vaccines at Pandemic Speed." The New England Journal of Medicine 2, no. 3 (2020).

Manan, Abdul. Aneka Masalah Hukum Perdata Islam di Indonesia. Jakarta: Prenada Media, 2008.

Manan, A. "Penemuan Hukum oleh Hakim dalam Praktek Hukum Acara di Peradilan Agama." Jurnal Hukum Dan Peradilan 2, no. 2 (2013).

Masrur, Imam. "Konsep Nasikh Mansukh Jalauddin Al-Suyuti dan Implikasi Metode Pengajarannya di Perguruan Tinggi." Realitas Journal 16, no. 1 (2018).

Nurvitasari. "Asma Binti Abubakar: Peranannya dalam Hijrah Nabi Muhammad SAW ke Madinah dan Periwayatan Hadis." Undergraduate thesis, Surabaya: State Islamic University of Sunan Ampel, 2004.

Quraish Shihab, Muhammad. Tafsir Al-Misbah: Pesan, Kesan dan Keserasian Alquran. Jakarta: Lentera Hati, 2005.

Ridwansyah, Muhammad. "Nafkah Anak Luar Kawin Menurut Konsep Hifzhul Al-Nafs." Jurnal Yudisial 8, no. 1 (2015).

Riyani, Irma. "Menelusuri Latar Historis Turunya Alquran dan Proses Pembentukan Tatanan Masyarakat Islam." Al-Bayan: Jurnal Studi Alquran dan Tafsir 1, no. 1 (June 2016).

Sarong, Hamid. Hukum Perkawinan di Indonesia. Banda Aceh: Pena, 2010.

Sunart, Euis. "Perumusan Ukuran Ketahanan Keluarga." Media Gizi dan Keluarga 27, no1, 2003.

Sunarti Euis. "Studi Ketahanan Keluarga dan Ukurannya: Telaah Kasus Pengaruhnya terhadap Kualitas Kehamilan.” Thesis doctoral, Graduate Program Bogor Agritucal University, 2001.

Syahnan, Mhd., Mahyuddin, Abd. Mukhsin. "Reconsidering Gender Roles in Modern Islam: A Comparison of the Images of Muslim Women Found in the Works of Sayyid Qutb and 'Â'ishah 'Abd Rahmân.” International Journal of Humanities and Social Science Invention 6, no. 10 (2017). 
Ridwan Nurdin, et al.: Reconsidering Nafaqah of Family Resilience During The Covid-19

Syahnan, Mhd. "The Image of the Prophet and the Systematization of Ushul al-Fiqh: A Study of al-Shafi'i's Risalah,” Jurnal Miqot, no. 103 (1998).

Syahnan, Mhd. and Abd. Mukhsin, "Islamic Law of Procedure: An Analysis of Kitâb al-Qâdhî ila al-Qâdhî in Islamic Legal Literature." Islamijah: Journal of Islamic Social Sciences 1, no. 1 (2020).

Syahuri,T.Legislasi Hukum Perkawinan di Indonesia: Pro dan Kontra Pembentukannya hingga Putusan Mahkamah Konstitusi. Jakarta: Kencana Prenada Media, 2013. 